\title{
Impaired antioxidant defence in guinea pig heart tissues treated
}

I. Durak PhD, ${ }^{\star}$ O. Kurtipek MD, ${ }^{\dagger}$

H.S. Öztürk MD PhD, ${ }^{*} M$. Birey PhD, ${ }^{\ddagger}$

T. Güven PhD, ${ }^{\ddagger}$ M. Kavutcu PhD, ${ }^{*}$

M. Kaçmaz MD, ${ }^{*}$ B. Dikmen MD, ${ }^{\dagger}$

M. Yel PhD, $\$$. Canbolat MD PhD*

Purpose: To investigate the effects of halothane and halothane plus vitamin $E$ treatment on myocardial free radical metabolism in guinea pigs.

Methods: Four groups of seven animals were studied; control, halothane. halothane plus vitamin $E$ and vitamin $E$ groups. In the halothane group, halothane $1.5 \%$ in oxygen was given for $90 \mathrm{~min}$ over three days. In the halothane plus vitamin $E$ group, $300 \mathrm{mg}^{\prime} \mathrm{kg}^{-1}$. day' vitamin $\mathrm{E}$ im was started three days before the first halothane treatment and continued for three days. Following sacrifice, the hearts were assayed for superoxide dismutase (SOD), glutathione peroxidase (GSH-Px) and catalase (CAT) and malondialdehyde (MDA) level was determined. Electron spin resonance (ESR) analysis and electron microscopy (EM) were also performed.

Results: In the halothane group, SOD activities and MDA concentrations were increased compared with control and GSH-Px and CAT activities were decreased. In the halothane plus vitamin E group, there were no differences in enzyme activity compared with halothane alone but the MDA level was decreased. In the vitamin E group, enzyme activities were increased compared with control. Mainly the $\mathrm{CF}_{3} \mathrm{CHCl}$ radical was identified by ESR analysis in heart tissues exposed to halothane and the concentration of this radical was reduced by vitamin $\mathrm{E}$. Electron microscopy showed cytoplasmic vacuolisation and dilation in sarcoplasmic reticulum in the heart tissues exposed to halothane: both were prevented by vitamin $\mathrm{E}$.

Conclusion: Although halothane causes impairment in enzymatic antioxidant defence potential, due to lowered GSH-Px and CAT activity, and accelerates peroxidative reactions in the tissues affected, no subcellular damage occurred. Vitamin $E$ may protect tissues against free radical attack by scavenging toxic free radicals formed in heart tissue during halothane anaesthesia.

Objectif : Étudier les effets de l'halothane et de l'association halothane-vitamine E sur la production myocardique de radicaux libres.

Méthodes : L'étude portait sur quatre groupes de sept animaux : contrôle, halothane, halothane + vitamine $E$, et vitamine $E$. Le groupe halothane a reçu de l'halothane $1.5 \%$ en oxygène pendant 90 min pour 3 jours. Le groupe halothane + vitamine $E$ a reçu une dose im de $300 \mathrm{mg}^{\circ} \mathrm{kg}^{-1} \cdot j^{-1}$ de vitamine $E$ pendant trois jours avant un premier traitement à l'halothane. Une fois l'animal sacrifié, la superoxyde dismutase (SOD), la glutathion peroxydase (GSH-Px) et catalase (CAT), et la malondialdéhyde (MDA) ont été titrées dans le tissu cardiaque. La résonance paramagnétique électronique (RPÉ) et la microscopie électronique ont complété ces analyses.

Résultats : Dans le groupe halothane, l'activité de la SOD et la concentration de MDA augmentaient comparativement au controle et l'activité de la GSH-Px et de la CAT diminuait. Dans le groupe halothane + vitamine E, l'activité enzymatique ne changeait pas comparativement à l'halothane seul mais le niveau de MDA diminuait. Dans le groupe

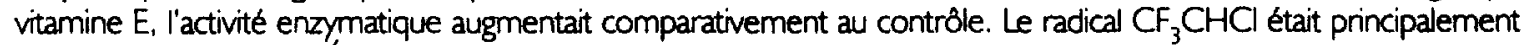
identifié par l'analyse RPÉ dans le tissu cardiaque exposé à l'halothane alors que la vitamine E diminuait la concentration de ce radical. La microscopie électronique révélait une vacuolisation et une dilatation cytoplasmiques du réticulum sarcoplasmique du tissu cardiaque exposé à l'halothane ; la vitamine $E$ prévenait ces effets.

Conclusion : Malgré l'altération par l'halothane de la capacité de protection enzymatique contre l'oxydation, due à la baisse de l'activité de la GSH-Px et de la CAT, et l'accélération des réactions peroxydatives dans les tissus affectés, il n'y a pas eu de dommages infracellulaires. La vitamine E protège les tissus contre l'agression des radicaux libres en épurant les radicaux toxiques libérés dans le tissu candiaque pendant l'anesthésie à l'halothane.

From the Department of ${ }^{\star B i o c h e m i s t r y, ~ A n k a r a ~ U n i v e r s i t y ~ M e d i c a l ~ F a c u l t y, ~}{ }^{\dagger}$ Anesthesiology Clinics, Ibn-i Sina and Numune Hospirals, ${ }^{\star B i o l o g y}$ and Physics Departments, Ankara University Science Faculty and the SBiology Department, Gazi University Education Faculty, Ankara. Address correspondence to. Prof. Dr. Ilker Durak, Ankara Üniversitesi Tip Fakültesi, Biyokimya A.B.D (Dekanlik Binasi), 06100 Sihhiye Ankara/Turkey; Phone: (90) 31230922 19; Fax: (90) 3123106370.

Accepted for publication May 15, 1997. 


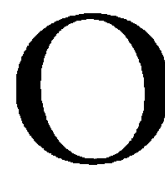

XIDATIVE processes are involved in a variety of pathological conditions and free radical species may play a part in the pathogenesis of myocardial tissue injury associated with ischaemia and reperfusion processes during and after cardiac operations. ${ }^{1-4}$ Free radical production starts during ischaemia, ${ }^{5,6}$ which is associated with a depletion of tissue antioxidants including superoxide dismutase (SOD), glutathione and vitamin E. ${ }^{7-9}$ This phenomenon occurs to a much greater extent during reperfusion when reactive hyperaemia supplies abundant amounts of oxygen. ${ }^{10}$ Secondly, restoration of coronary blood flow just after an ischaemic period during cardiac surgery also brings an additional source of free radicals consisting of polymorphonuclear leucocytes (PMNs). ${ }^{11}$ As a result, free radical-mediated harmful effects such as loss of normal mitochondrial and sarcoplasmic reticulum function, disturbed membrane permeability and disruption of cellular transport processes may occur during and/or after cardiac surgery, all of which are typical ischaemia/reperfusion injury. ${ }^{12}$

Some anaesthetics, including halothane, appear to exert differential effects on the severity of such injury. The effects of volatile anaesthetics on this type of injury may be due to their radical character (the chemical structure of $\mathrm{CF}_{3} \mathrm{CHClBr}$, may convert to the $\mathrm{CF}_{3} \mathrm{CHCl}$ radical in living cells) and/or to their effects on the tissue antioxidant defence system. The cardiovascular effects of volatile anaesthetics including halothane are well known. ${ }^{13}$ Tanguay et al. suggested that volatile agents have exert beneficial effects on free radical-mediated damages but the mechanism is not known. ${ }^{14}$ They proposed that volatile anaesthetics prevented or attenuated the reduction in coronary flow induced by oxygen free radicals and, thus, enhanced myocardial recovery during reperfusion. ${ }^{14}$ However, halothane is known to have toxic effects in some people and its toxicity arises mainly from altered free radical metabolism in affected tissues such as the liver, heart, kidney, lung. ${ }^{15-17}$ Godin et al. found that myocardial SOD activity increased in halothane-anaesthetized animals but other free radical metabolising enzyme activities was minimally affected. They suggested that the influence of anaesthetics on the course of ischaemia/reperfusion injury is not likely to occur at the level of enzymatic antioxidant component. ${ }^{18}$ In contrast to suggestions that halothane exerts beneficial effects on free radical-mediated cell damages, halothane may have deleterious effects on some tissues and cells due to its radical character. ${ }^{15-17}$

We investigated the effects of halothane on heart tissue, to establish whether vitamin $\mathrm{E}$, one of the most powerful of cellular antioxidants that passes easily through the membrane lipid bilayer and enters cells owing to its hydrophobic chemical structure, has a protective function against peroxidation reactions occurring in heart tissue during halothane anaesthesia.

\section{Methods}

\section{Chemicals}

Halothane was obtained from Hoechst and Vitamin E from Roche Corporations. All chemicals used in the experiments were of analytical grade.

\section{Animals}

Twenty-eight guinea pigs (two-months-old, approx. $450 \mathrm{~g}$ ) were used throughout the experiments. They were divided into four groups of seven; control, halothane, halothane plus vitamin $\mathrm{E}$ and vitamin $\mathrm{E}$ alone. The animals were fed a laboratory diet during the study. Intramuscular vitamin $\mathrm{E}$ injection (300 $\mathrm{mg} \cdot \mathrm{kg}^{-1} \cdot \mathrm{day}^{-1}$ ) was started three days before the first halothane treatment and continued for three days. The animals in the vitamin $\mathrm{E}$ group were given vitamin $\mathrm{E}$ alone $\left(300 \mathrm{mg} \cdot \mathrm{kg}^{-1} \cdot \mathrm{day}^{-1}\right)$ and those in the control group, physiological saline solution for six days. Halothane $1.5 \%$ in oxygen mixture was given to the animals at the rate of $2 \mathrm{~L} \cdot \mathrm{min}^{-1}$ for $30 \mathrm{~min}$ each day for three days. Gas mixtures were inspired using face masks. At the end of the experiments (two days after the last halothane treatment), the animals were killed by cervical dislocation and their hearts were taken in ice bath until homogenisation for about one hour. Part of each heart was immediately placed in a nitrogen tank for electron spin resonance (ESR) assays and another part was put in glutaraldehyde 3\% solution for electron microscopic examination. Inferior vena cava blood was taken for routine blood assay.

\section{Preparation and analysis}

Hearts were first washed with deionized water to discard blood and then homogenized in an homogenisator (B.Braun Melsungen model) at $1000 \mathrm{U}$ for about three minutes. After centrifugation at $10,000 \mathrm{~g}$ for about 60 $\mathrm{min}$, the upper layer was taken. In this fraction protein, glutathione peroxidase (GSH-Px), superoxide dismutase (SOD) and catalase (CAT) activities were measured as previously described. ${ }^{19-22}$ One unit of SOD activity was defined as the amount of protein causing $50 \%$ inhibition in nitroblue tetrazolium salt (NBT) reduction rate. The CAT and GSH-Px activities were given in IU. $\mathrm{mg}^{-1}$ protein and SOD activity in U. $\mathrm{mg}^{-1}$ protein. The MDA concentration was determined by using the thiobarbutiric acid reaction. ${ }^{23}$ The activity of LDH and AST in serum was measured in routine biochemistry laboratory. All experiments were carried out at $+4^{\circ} \mathrm{C}$. In order to eliminate contamination errors due to presence of blood in the heart tissue and to obtain real values for the parameters studied, we used the equation shown on page 1016. 


\section{Equation:}

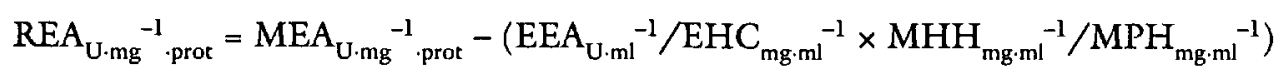

(REA: Real Enzyme Activity, MEA: Measured Enzyme Activity, EEA: Erythrocyte Enzyme Activity, EHC: Erythrocyte Haemoglobin Content, MHH: Measured Haemoglobin in Homogenate, MPH: Measured Protein in Homogenate)

\section{Precision analysis of the methods}

A; Within (ten assays a day) and, B; Between (one assay a day in consecutive ten days) batch analysis were performed (Table I).

\section{Electron microscopy}

Specimens for electron microscopy were fixed in cold phosphate buffer ( $\mathrm{pH} 7.2$ ) containing glutaraldehyde $3 \%$ solution for two hours. After postfixation in osmium tetroxide $1 \%$ solution for one hour, each block was dehydrated in graded ethanol solutions, embedded in araldite CY 212 and allowed to polymerise at $60^{\circ} \mathrm{C}$ for two days before sectioning. Each section was mounted on a 400 mesh copper gride, double stained with uranyl acetate and lead citrate (Sato) and examined with a JEOL EM-100 CX-II transmission electron microscope.

\section{Electron spin resonance (ESR) analysis}

The spectra of the samples were recorded with a Varian X-Band E 109 C Model ESR spectrometer and investigated between $100-300 \mathrm{~K}$. The $\mathrm{g}$ and a values were obtained by comparison of the centres of gravity of the spectra with a DPPH sample $g=2.0036$. The conditions used were: Scan range $2000 \mathrm{G}$, power $6 \mathrm{~dB}$, gain $2.5 \times 10^{3}$, microwave frequency 9.105 Ghz, field setting $3250 \mathrm{G}^{24,25}$

\section{Statistics}

In the statistical analysis, Tukey's HSD (honestly significant difference, ANOVA) procedure was used.

\section{Results}

\section{Oxidant/antioxidant parameters}

Tissue SOD activities were higher and GSH-Px and CAT activities lower in the halothane-treated groups (Groups II and III) than in the control group. The
SOD activities were $23.93 \pm 6.39$ in the control group, $28.32 \pm 5.69$ in group II and $29.73 \pm 2.24$ in group III. GSH-Px activities were $50.66 \pm 5.33$ in the control group, 40.62 \pm 6.73 in group II and $41.60 \pm 4.40$ in group III. The CAT activities were $12.88 \pm 3.90$ in control group, $9.58 \pm 3.39$ in group II and $9.80 \pm 3.59$ in group III. In the vitamin E group (Group IV), all enzyme activities in the heart tissues were elevated relative to the control group $(P<0.05$ for SOD, $P<0.05$ for GSH-Px and $P<0.005$ for CAT). In the halothane group, tissue MDA levels were higher than those of control $(P<0.0005)$ and vitamin $(P<0.0005)$ groups (Table II).

\section{Serum parameters}

Serum AST activity was moderately increased in the halothane group, but no differences were found between serum LDH activities of the groups (Table III). Increased AST values probably resulted from hepatic damages rather than cardiac changes.

\section{Correlation analysis}

There were differences between halothane-treated groups and control group with regard to correlation coefficient values. There were negative correlations between GSH$\mathrm{Px} / \mathrm{CAT}(\mathrm{r}=-0.67)$ and CAT/MDA $(\mathrm{r}=-0.69)$ and $\mathrm{a}$ positive correlation between SOD/MDA $(r=-0.79)$ in the control group. However, there were no correlations between these parameters in the halothane treated groups. Similarly, there was a negative correlation between GSH-Px/MDA in the control group $(r=-0.50)$, but a positive correlation $(r=0.74)$ in the halothane group. Accordingly, there were similarities between correlation values of control and vitamin E groups, except between GSH-Px/CAT, which was negative in the control group and positive in vitamin group. The relationships between enzyme activities of antioxidant defence

TABLE I Precision analysis results of the methods.

\begin{tabular}{|c|c|c|c|c|}
\hline & $\begin{array}{l}\text { Superoxide } \\
\text { dismutase }\end{array}$ & $\begin{array}{l}\text { Glutathione } \\
\text { peroxidase }\end{array}$ & Catalase & $\begin{array}{l}\text { Malondi- } \\
\text { aldebyde }\end{array}$ \\
\hline$A(n=10) C V \%$ & 5.8 & 5.9 & 6.8 & 6.3 \\
\hline$B(n=10) \quad C V \%$ & 4.8 & 6.9 & 5.2 & 7.2 \\
\hline
\end{tabular}

A; Within batch analysis, carried out by performing ten assays a day with the same sample.

B; Between batch analysis, carried out by performing one assay a day for consecutive ten days. 
TABLE II SOD (U. $\left.\mathrm{mg}^{-1}\right)$, GSH-Px $\left(\mathrm{mIU} \cdot \mathrm{mg}^{-1}\right)$, CAT $\left(\mathrm{IU} \cdot \mathrm{mg}^{-1}\right)$ activities and MDA $\left(\mu \mathrm{g} \cdot \mathrm{g}\right.$ protein $\left.{ }^{-1}\right)$ concentrations in heart tissues of the groups.

\begin{tabular}{lllll}
\hline Groups & $S O D$ & $G S H-P x$ & $C A T$ & $M D A$ \\
\hline I (n=7) & $23.93 \pm 6.39$ & $50.66 \pm 5.53$ & $12.88 \pm 3.90$ & $1.03 \pm 0.15$ \\
II (n=7) & $28.32 \pm 5.69$ & $40.62 \pm 6.73$ & $9.58 \pm 3.39$ & $2.05 \pm 0.42$ \\
III (n=7) & $29.73 \pm 2.24$ & $41.60 \pm 4.40$ & $9.80 \pm 3.59$ & $0.80 \pm 0.16$ \\
IV (n=7) & $28.30 \pm 6.10$ & $64.20 \pm 8.60$ & $18.50 \pm 4.12$ & $0.70 \pm 0.18$ \\
Statistical cvaluation & & & & \\
I-II & $P<0.05$ & $P<0.05$ & $P<0.05$ & $P<0.0005$ \\
I-III & $P<0.05$ & $P<0.005$ & $P<0.05$ & $P<0.0005$ \\
I-IV & $P<0.05$ & $P<0.05$ & $P<0.005$ & $P<0.005$ \\
II-III & n.s. & n.s. & n.s. & $P<0.0005$ \\
III-IV & n.s. & $P<0.01$ & $P<0.005$ & n.s. \\
\hline
\end{tabular}

I: Control, II: Halothane, III: Halothane + Vitamin E, IV: Vitamin E

n.s: non significant

TABLE III Activities (Mean \pm SD) of lactate dehydrogenase $\left(\mathrm{U} \cdot \mathrm{L}^{-1}\right)$ and aspartate amino transferase $\left(\mathrm{U} \cdot \mathrm{L}^{-1}\right)$ in serum from guinea pigs.

\begin{tabular}{lll}
\hline Groups & $L D H$ & $A S T$ \\
\hline I & $542.4 \pm 115.2$ & $22.5 \pm 6.5$ \\
II & $606.4 \pm 280.2$ & $30.2 \pm 11.2$ \\
III & $605.2 \pm 230.4$ & $26.6 \pm 9.3$ \\
IV & $570.6 \pm 240.4$ & $24.5 \pm 12.3$ \\
Statistical evaluation & & \\
I-II & ns & $P<0.05$ \\
I-III & ns & ns \\
II-III & ns & ns \\
I-IV & ns & ns \\
\hline
\end{tabular}

I: Control, II: Halothane, III: Halothane + Vitamin E, IV: Vitamin E

ns: Non significant $(P>0.05)$ system were disordered in the halothane-treated groups (Groups II, III) (Table IV).

\section{ESR analysis}

In the ESR analysis, a spectrum consisted of four lines whose four components were in the approximate intensity ratio of $1: 3: 3: 1$, was obtained in the heart tissue of the halothane group. This was in accordance with $\mathrm{CF}_{3} \mathrm{CHCl}$ radical lines as established in previous studies. ${ }^{24,25}$ No specific spectrum were obtained in the other groups (Table V).

\section{Electron microscopy}

In the electron micrographs, large vacuoles in cytoplasm and dilation in sarcoplasmic reticulum were

TABLE IV Correlation coefficient values between enzyme activities in the groups.

\begin{tabular}{lllllll}
\hline Groups & GSH-Px/SOD & GSH-Px/CAT & GSH-Px/MDA & $S O D / C A T$ & $S O D / M D A$ & CAT/MDA \\
\hline I & n.c. & -0.67 & -0.50 & -0.70 & 0.79 & -0.69 \\
II & n.c. & n.c. & 0.74 & -0.76 & n.c. & n.c. \\
III & 0.66 & n.c. & -0.81 & -0.62 & n.c. & n.c. \\
IV & n.c. & 0.60 & -0.50 & -0.60 & 0.60 & 0.70 \\
\hline
\end{tabular}

I: Control, II: Halothane, III: Halothane + Vitamin E, IV: Vitamin E

n.c.: No correlation $(P>0.05)$

TABLE V Some parameters in the heart tissues at $140 \mathrm{~K}$ in ESR analysis

\begin{tabular}{llll}
\hline Control Group & Halothane Group & Halot. + Vit. Group & Vit.Group \\
\hline NTS & $\mathrm{CF}_{3} \mathrm{CHCl}$ & $\mathrm{NTS}$ & $\mathrm{NTS}$ \\
$\mathrm{a}=0$ & $\mathrm{a}=145 \mathrm{Gauss}$ & $\mathrm{a}=0$ & $\mathrm{a}=0$ \\
$\mathrm{~g}=2.0032$ & $\mathrm{~g}=2.0035$ & $\mathrm{~g}=2.0033$ & $\mathrm{~g}=2.0032$ \\
$\mathrm{RRC}=2.4 \pm 0.3$ & $\mathrm{RRC}=10.8 \pm 0.3$ & $\mathrm{RRC}=3.1 \pm 0.3$ & $\mathrm{RRC}=2.6 \pm 0.3$ \\
\hline
\end{tabular}

NTS: Normal tissue spectrum

a: Hyperfine splitting constane

g: Spectroscopic splitting factor

RLC: Relative radical concentration / g tissue 


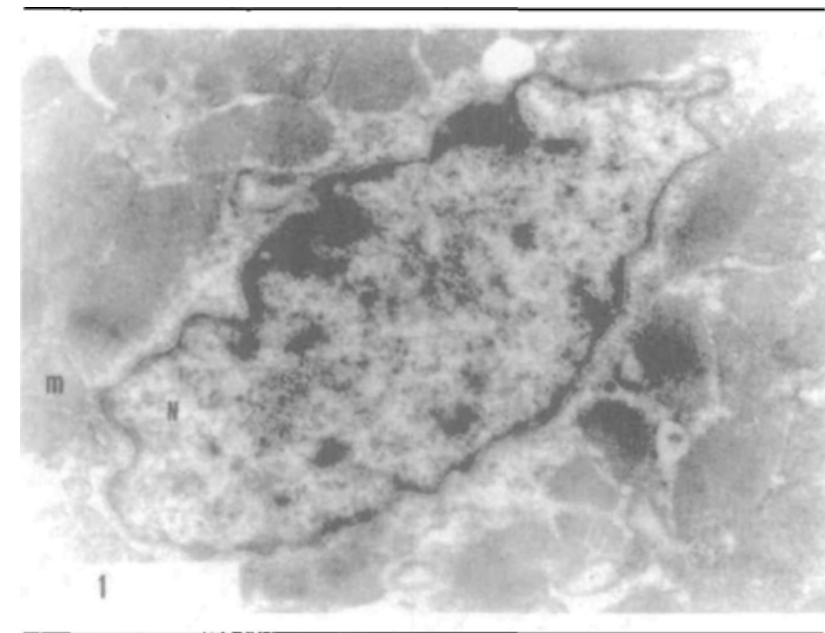

FIGURE 1 Electron micrograph of cardiac muscle cell from control guinea pig. Mitochondrium(m), nucleus(N). $\times 13600$

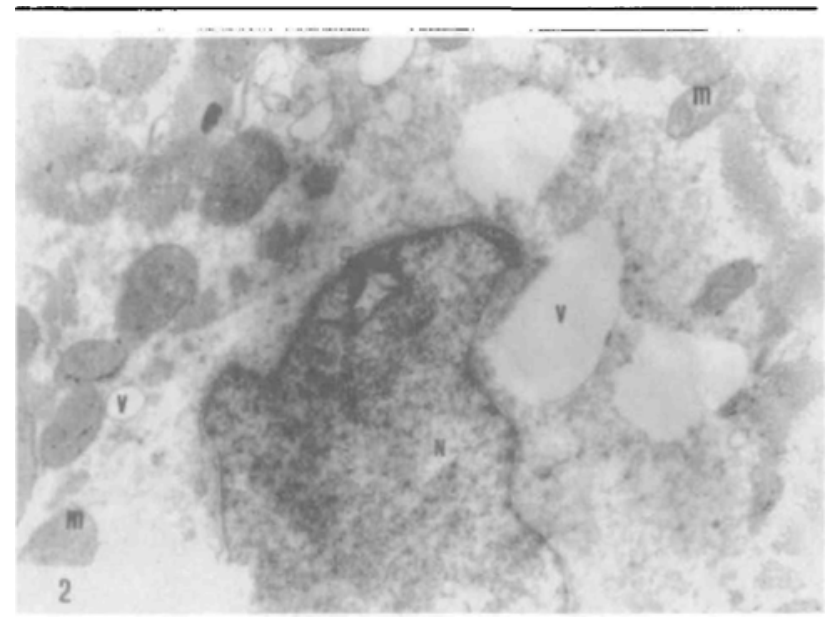

FIGURE 2 Electron micrograph of cardiac muscle cell from guinea pig exposed to halorhane. Note the large vacuoles(v) in sarcoplasm. Mitochondria(m), nucleus(N). $\times 13600$

observed in the heart tissues exposed to halothane (Figures $1 \& 2$ ). Although these were not normal changes, the mechanism of their occurrence and its importance were not clear. In the halothane plus vitamin $\mathrm{E}$ group, no vacuoles were seen (Figure 3). In the vitamin $\mathrm{E}$ group, the nucleus was euchromatic, which was an indication of accelerated metabolic activity in the myocardial cells. (Figure 4)

\section{Discussion}

Several reports indicate that halothane is associated with occasional toxicity, particularly hepatotoxicity ${ }^{26}$ Although the exact mechanism is not understood, there is experimental evidence suggesting that radical-

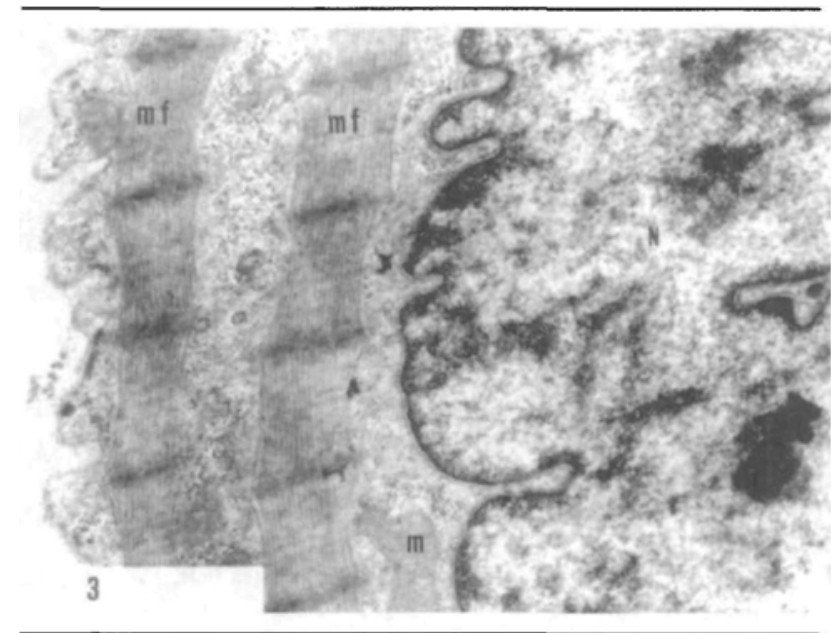

FIGURE 3 Electron micrograph of cardiac muscle cell from guinea pig exposed to halochane plus vitamin $E$ treatment. Nucleus(N), mitochondrium(m), myofibrilles(mf). $\times 19000$

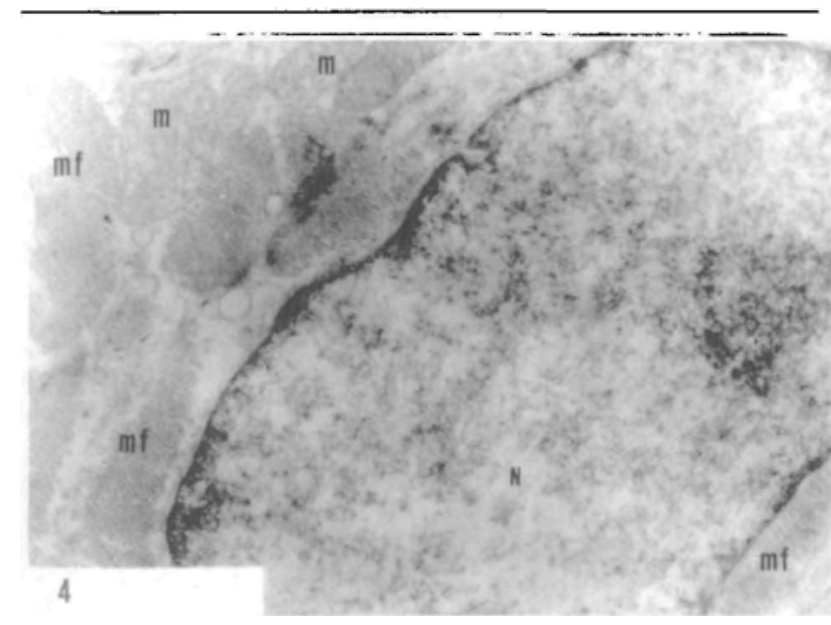

FIGURE 4 Electron micrograph of cardiac muscle cell from guinca pig treated with vitamin $\mathrm{E}$ alone. Note that the nucleus is euchromatic. Mitochondria $(m)$, nucleus $(N)$, myofibrilles in oblique section $(\mathrm{mf}) . \times 19000$

mediated processes play an important part. ${ }^{27-29}$ It has been suggested that some reactive intermediates created during halothane metabolism are involved in cell death, perhaps through their ability to bind covalently to free amino groups in subcellular proteins. ${ }^{27}$ Others suggest that, although most of the halothane metabolism in vive is by the oxidative route, ${ }^{15,30,31}$ hypoxia leads to cellular degeneration. ${ }^{28}$ This second route, the reductive pathway, generates free radical intermediates. Toxic free radicals produced by reductive pathway are held responsible of the halothane toxicity. ${ }^{28,30,31}$

Several studies indicate that halothane has effects on heart tissue mainly by changed free radical metabolism. ${ }^{16-18}$ In one study myocardial SOD activity was 
increased in halothane-anaesthetized animals but other antioxidant enzyme activities were unchanged. ${ }^{18}$ It has been suggested that the influence of anaesthetics on the course of ischaemia and reperfusion injury involved antioxidant components ${ }^{18}$ In other studies, it has been argued that halothane prevents free radical-induced reduction of coronary perfusion and heart contractility; volatile agents have beneficial effects on the free radical cell damage pathway.14,17 However, no mechanism has been presented of the beneficial effect of halothane on heart tissue. Indeed it is not clear whether it exerts beneficial or harmful effects on heart tissue.

If halothane causes peroxidative reactions in heart tissue as in the liver, it is expected that free radical damage could occur during the ischaemia/reperfusion period in cardiac surgery. In cardiac operations, it has been established that free radical production starts during the ischaemic period ${ }^{5,6}$ and continues during reperfusion when reactive hyperaemia supplies abundant amounts of oxygen. ${ }^{10}$ Secondly, restoration of coronary blood flow brings additional free radicals, mainly from polymorphonuclear leucocytes (PMNs). ${ }^{11}$ As a result, free radical-mediated harmful effects, such as loss of normal mitochondrial and sarcoplasmic reticulum function, disturbed membrane permeability, and disruption of cellular transport processes, may occur in the heart tissues affected ${ }^{12}$ and this can be aggravated by halothane due to its radical character.

Although SOD activity increased, GSH-Px and CAT activities decreased in heart tissue from animals anaesthetized with halothane relative to controls (Table II). There might be several reasons for this alteration in enzyme activity and halothane and/or one of its metabolites might play a part. Differential depletion or activation of the enzymes might be also occur but the mechanisms involved are not known. Enzymatic relations were also found to be disturbed in halothanetreated groups compared with controls (Table IV). Tissue MDA concentration in this group was higher, indicating accelerated peroxidation reactions in the heart tissue exposed to halothane. In the halothane plus vitamin $E$ group, the $\mathrm{MDA}$ concentration was reduced. Since enzyme activities are not changed in halothane plus vitamin $\mathrm{E}$ group compared with halothane alone (Table II), it seems that vitamin E may exert its effect not through enzyme activities but, through its antioxidant property. This finding (lowered MDA concentration) demonstrated that vitamin $\mathrm{E}$ treatment prevented lipid peroxidation and protected heart tissue against free radical attacks. Vitamin $\mathrm{E}$ is a powerful antioxidant and it can scavenge some radical species by taking their unpaired single electron upon its own. Since, due to its hydrophobic character, it can pass through the mem- brane lipid bilayer it can also function within the cell as a radical quencher.

Increased myocardial lipid peroxidation in the halothane group might arise from either increased oxygen radical concentrations due to changed enzymatic antioxidant capacity of the heart tissue and/or high amounts of $\mathrm{CF}_{3} \mathrm{CHCl}$ radical formed in the heart tissue. The changes in the antioxidant enzyme activities may lead to $\mathrm{H}_{2} \mathrm{O}_{2}$ accumulation in the myocardial cells, which then give rise to the hydroxy radical $(\mathrm{OH})$ formation in large amounts through Haber-Weiss and Fenton reactions. The $\mathrm{OH}$ - radical is one of the most toxic radicals, which easily reacts with cellular structures and causes subcellular damages. In addition to these kinds of radical damages, $\mathrm{CF}_{3} \mathrm{CHCl}$ radical derived from halothane may accelerate peroxidation reactions. Using electron microscopy, some changes were observed in the heart tissues exposed to halothane. This demonstrates that halothane causes oxidant stress, accelerates peroxidation reactions and leads to some changes in the myocardial cells.

We suggest that the effect of halothane on the myocardial antioxidant defence system is important, especially when combined with the ischaemia and reperfusion processes as occurs in some cardiac operations and, vitamin $\mathrm{E}$ pretreatment might protect the myocardium against free radical attacks during halothane anaesthesia.

\section{References}

1 Menasché $P$, Piwnica A. Free radicals and myocardial protection: a surgical viewpoint. Ann Thorac Surg 1989; 47: 939-45.

2 Freeman BA, Crapo JD. Biology of disease. Free radicals and tissue injury. Lab Invest 1982; 47: 412-26.

3 Hammond $B$, Hess $M L$. The oxygen free radical system: potential mediator of myocardial injury. I Am Coll Cardiol 1985; 6: 215-20.

4 Werns $S W$, Shea MJ, Lucchesi BR. Free radicals and myocardial injury: pharmacologic implications. Circulation 1986; 74: 1-5.

5 Romaschin $A D$, Rebeyka I, Wilson GJ, Mickle DA. Conjugated dienes in ischemic and reperfused myocardium: an in vivo chemical signature of oxygen free radical mediated injury. J Mol Cell Cardiol 1987; 19: 289-302.

6 Del Nido PJ, Mickle DAG, Wilson GJ, et al. Evidence of myocardial free radical injury during elective repair of tetralogy of Fallot. Circulation 1987; 76: V174-9.

7 Julicher RHM, Tijburg LBM, Sterrenberg L, Bast A, Koomen JM, Noodhoek J. Decreased defense against free radicals in rat heart during normal reperfusion after hypoxic, ischemic and calcium-free perfusion. Life Sci 1984; 35: 1281-8. 
8 Röth E, Török B, Zsoldos T, Matkovics B. Lipid peroxidation and scavenger mechanism in experimentally induced heart infarcts. Basic Res Cardiol 1985; 80: 530-6.

9 Ferrari $R$, Ceconi $C$, Curello $S$, et al. Oxygen-mediated myocardial damage during ischaemia and reperfusion: role of the cellular defences against oxygen toxicity. J Mol Cell Cardiol 1985; 17: 937-45.

10 Gauduel $Y$, Duvelleroy $M A$. Role of oxygen radicals in cardiac injury due to reoxygenation. J Mol Cell Cardiol 1984; 16: 459-70.

11 Lucchesi $B R$, Romson $J$, Jolly $S R$. Do leucocytes influence infarct size? In: Hearse DJ, Yello DM. (Eds.). Therapeutic Approaches to Myocardial Infarct Size Limitation. New York: Raven Press, 1984: 219-48.

12 Nayler WG, Elz JS. Reperfusion injury: laboratory artifact or clinical dilemma? Circulation 1986; 74: 215-20.

13 Blake DW, Way D, Trigg L, Langton D, McGrath BP. Cardiovascular effects of volatile anesthesia in rabbits: influence of chronic heart failure and enalaprilat treatment. Anesth Analg 1991; 73: 441-8.

14 Tanguay $M$, Blaise $G$, Dumont L, Beique G, Hollmann $C$. Beneficial effects of volatile anesthetics on decrease in coronary flow and myocardial contractility induced by oxygen-derived free radicals in isolated rabbit hearts. J Cardiovasc Pharmacol 1991; 18: 863-70.

15 Gut J, Cbristsen U, Huwyler J. Mechanisms of halothane toxicity: novel insights. Pharmacol Ther 1993; 58: 133-55.

16 Kirshenbaum $L A$, Singal $P K$. Antioxidant changes in heart hypertropy: significance during hypoxia-reoxygenation injury. Can J Physiol Pharmacol 1992; 70: 1330-5.

17 Tanguay M, Blaise GA, Hollmann $C$, Amyot $\Upsilon$, Beique $G, M e l o c h e ~ R$. Halothane and isoflurane prevent free radical induced reduction in the coronary flow and contractility of the isolated rabbit-heart. Can J Anaesth 1990; 37: $\$ 147$.

18 Godin DV, Garnett ME. Effects of various anesthetic regimens on tissue antioxidant enzyme activities. Res Common Chem Pathol Pharmacol 1994; 83: 93-101.

19 Lowry $O$, Rosenbraugh $N$, Farr $L$, Rondall $R$. Protein measurement with the folin phenol reagent. J Biol Chem 1951; 183: 265-75.

20 Paglia $D E$, Valentine $W N$. Sudies on the quantitative and qualitative characterization of erythrocyte glutathione peroxidase. J Lab Clin Med 1967; 70: 158-69.

21 Durak I, Canbolat O, Kavuţu M, Öztürk HS, Yurtarslani $Z$. Activities of total, cytoplasmic, and mitochondrial superoxide dismutase enzymes in sera and pleural fluids from patients with lung cancer. J Clin Lab Anal 1996; 10: 17-20.

22 Aebi H. Catalase. In: Bergmeyer HU (Ed.). Methods of Enzymatic Analysis. New York and London: Academic Press Inc, 1974: 673.
23 Dable LK, Hill EG, Holman RT. The thiobarbituric acid reaction and autooxidations of polyunsaturated fatty acid methyl esters. Arc Biochem Biophys 1962; 98: 253-61.

24 Lontz RJ. Electron spin resonance analysis of a $\gamma$-irradiated single crystal of pentafluoropropionamide. Journal of Chemical Physics 1966; 45: 1339.

25 Rogers $M T$, Kispert LD. Trifluoromethyl, and other radicals, in irradiated single crystals of trifluoroacetamide. Journal of Chemical Physics 1967; 46: 3193-9.

26 Stock JGL, Strunin L. Unexplained hepatitis following halothane. Anesthesiology 1985; 63: 424-39.

27 Kenna JG, Satoh H, Christ DD, Pobl LR. Metabolic basis for a drug hypersensitivity: antibodies in sera from patients with halothane hepatitis recognize liver neoantigens that contain trifluoroacetyl group derived from halothane. J Pharmacol Exp Ther 1988; 245: 1103-9.

28 De Groot $H$, Noll $T$. Halothane hepatotoxicity: relation between metabolic activation, hypoxia, covalent binding, lipid peroxidation and liver cell damage. Hepatology 1983; 3: 601-6.

29 Durak I, Güven T, Birey $M$, et al. Halothane hepatotoxicity and hepatic free radical metabolism in guinea pigs; the effects of vitamin E. Can J Anaesth 1996; 43: 741-8.

30 Lind RC, Gandolfi AJ, Sipes IG, Brown BR Jr. Comparison of the requirements for hepatic injury with halothane and enflurane in rats. Anesth Analg 1985; 64: 955-63.

31 Lind $R C$, Gandolfi AJ, Hall $P$ de la $M$. The role of oxidative biotransformation of halothane in the guinea pig model of halothane-associated hepatotoxicity. Anesthesiology 1989; 70: 649-53. 